\title{
Sistem Informasi Pendapatan Jasa Pada Sekolah Mengemudi Ar'rahman
}

\author{
Siti Faizah ${ }^{1,{ }^{\star}}$, Ibnu Satria Fajar Al Afif ${ }^{2}$, Indah Ariyati ${ }^{3}$ \\ ${ }^{1}$ Teknik Informatika; Sekolah Tinggi Manajemen Informatika dan Komputer Nusa Mandiri; J. \\ Jatiwaringin Raya No.02 Cipinang Melayu Jakarta Timur,13620; e-mail: \\ siti.sfz@nusamandiri.ac.id \\ 2 Sistem Informasi Akuntansi; Universitas Bina Sarana Informatika Jakarta; Jl. Kramat Raya \\ No.98, Kwitang, Jakarta Pusat, 10450; e-mail: ibnusatriafa@gmail.com \\ ${ }^{3}$ Sistem Informasi; Universitas Bina Sarana Informatika Jakarta; Jl. Kramat Raya No.98, \\ Kwitang, Jakarta Pusat, 10450; e-mail: indah.ayi@bsi.ac.id \\ * Korespondensi: e-mail: siti.sfz@nusamandiri.ac.id
}

Diterima: 16 Nopember 2020; Review: 30 Nopember 2020; Disetujui: 14 Desember 2020

Cara sitasi: Faizah S, Afif ISFA, Ariyati I. 2020. Sistem Informasi Pendapatan Jasa Pada Sekolah Mengemudi Ar'rahman. Bina Insani ICT Journal. Vol. 7 (2): 125-134.

\begin{abstract}
Abstrak: Teknologi era revolusi industri 4.0 saat ini mengalami perkembangan yang dinamis, begitupun dengan komputer yang merupakan peralatan untuk mempermudah pekerjaan tersebut. Yayasan Ar'rahman adalah sekolah mengemudi yang membutuhkan tersedianya aplikasi untuk menunjang pencatatan pendapatan, sistem yang ada saat ini masih manual dari pencatatan customer yang daftar sampai penyimpanan berkas-berkas pendaftaran dan laporan, sehingga memungkinkan terjadinya kesalaan dalam pencatatan dan kurang akuratnya laporan yang disajikan. Metode penelitian yang penulis gunakan yaitu teknik dalam mengumpulkan data terdiri dari Observasi, Wawancara dan Studi Pustaka sedangkan metode pengembangan software terdiri dari analisis untuk kebutuhan perangkat lunak, perancangan, pengkodean, pengujian dan pendukung. Sistem ini menghasilkan informasi yang akurat dan relevan serta lebih kondusif untuk saat ini.
\end{abstract}

Kata kunci: pendapatan jasa, sistem informasi akuntansi.

Abstract: Technology in the era of the industrial revolution 4.0 is currently experiencing dynamic development, as well as computers which are equipment to make this job easier. The Ar'rahman Foundation is a driving school that requires an application to support income recording, the current system is still manual, from registering customers who register to storing registration files and reports, thus allowing errors in recording and inaccurate reports to be presented. The research method that the writer uses is the technique of collecting data consisting of observation, interview and literature study, while the software development method consists of analysis for software needs, design, coding, testing and support. This system produces accurate and relevant information and is more conducive to this moment.

Keywords: service revenues, accounting information systems.

\section{Pendahuluan}

Informasi yang berkembang saat ini begitu diterima oleh masyarakat seiring dengan kemajuan teknologi yang berkembang sangat pesat terutama dibidang informatika komputer. Manusia semakin menyadari bahwa komputer merupakan alat bantu manusia yang dapat mengolah data dengan cepat. Terlebih lagi dalam era modernisasi dan keuniversalan pada saat ini, manusia membutuhkan segala sesuatu yang serba cepat [1]. Kebutuhan masyarakat akan 
TI mengalami perkembangan yang dinamis. Teknologi informasi dan efisiensi waktu dalam kehidupan menjadi alasan utama masyarakat dalam menyajikan data yang sudah diolah dengan lebih cepat, lebih tepat dan akurat [2]. Maka diperlukannya suatu teknologi komputer untuk mempermudah dalam menjalankan suatu kegiatan usaha. Disemua bidang usaha, baik bidang perdagangan, industri maupun jasa. Berorientasi fleksibel, lebih mudah untuk dikembangkan. Peningkatan kinerja pada sistem dapat berpengaruh pada kecepatan, ketepatan dan keakuratan pada sistem. Untuk mengatasi masalah ini, diperlukan aplikasi yang sudah melakukan komputerisasi pada sistem [3].

Information system merupakan langkah suatu perkumpulan dalam pengumpulan, penginputan, pengolahan, penyimpanan, pengendalian dan pelaporan data, sehingga menghasilkan informasi untuk dapat mewujudkan tujuan organisasi [4]. Akuntansi merupakan suatu seni dalam mencatat, mengggolongkan, membuat ikhtisar, dan melaporkan terhadap adanya pertukaran yang berurutan dari sisi isi, dan sesuai dengan standar pada umumnya [5]. Akuntansi juga sebagai salah satu bahasa dalam organisasi. Perkembangan yang dinamis pada umumnya dapat mengakibatkan permasalahan yang semakin rumit dalam melakukan pencatatan, peringkasan, pelaporan, penginterprestasian data terhadap dasar ekonomi yang berhubungan dengan kepentingan pribadi, enterpreneur, government, dan lainnya [6]. Sistem dapat melakukan pengumpulan dan pemrosesan pertukaran data dalam penyampaian informasi dalam keuangan pada pihak yang terkait dinamakan information system akuntansi [7]. Peran akuntansi dalam sebuah perusahaan sangatlah diperlukan, mengingat semua perusahaan membutuhkan pengelolaan data dengan jelas yang bisa menunjang perusahaan.

UML (Unfield Modelling Language) adalah standar language yang sudah umum digunakan dalam perusahaan dalam menjelaskan requirement, membuat analysis dan perancangan, serta mendeskripsikan architecture pada object-oriented programming [8]. Code sebagai pembuatan klasifikasi dan input data pada komputer serta penyajian informasi yang berkonektivitas dengan data tersebut [9].

Java merupakan bahasa dalam pemrograman yang digunakan dalam berbagai sistem, dengan basis dekstop, basis web, basis mobile dan basis lainnya. Object-Oriented Programming dapat berjalan pada multiplatform operating system [10].

\section{Metode Penelitian}

Pada bagian ini peneliti menjelaskan tentang teknik dalam mengumpulkan data pada penelitian. Pertama, Metode Observasi (Observation Method) peneliti melakukan pengamatan langsung ke Sekolah mengemudi Ar'rahman untuk mengetahui tentang sistem laporan keuangan pendapatan jasa. Kedua, Metode Wawancara (Interview) Peneliti melakukan tanya jawab kepada ibu Vera selaku Accounting sekolah mengemudi Ar'rahman, untuk mengetahui data-data yang berhubungan dengan sistem laporan keuangan. Ketiga, Metode Studi Pustaka (Library Method) penulis mengumpulkan data dan literature dari buku-buku serta teori-teori terkait dengan judul penelitian ini.

Metode pengembangan software pada penelitian ini diantaranya. Pertama, Analisa Kebutuhan Software dimana peneliti menganalisis keperluan yang berhubungan dengan dokumen masukan berupa Formulir Pendaftaran Peserta dan dokumen keluaran berupa Kwitansi dan desain interface yang akan ditampilkan. Kedua, Desain yaitu peneliti merancang suatu aplikasi berdasarkan keperluan. Dimulai dengan alur perancangan dengan UML (Unfield Modelling Language), merancang database. Ketiga, Pengkodean yaitu peneliti merancang interface dengan software Java NetBeans IDE 8.1. Keempat, Pengujian yaitu peneliti melakukan pengujian black-box terhadap software yang sudah dibuat, apakah sudah sesuai dengan sistem informasi pendapatan jasa. Kelima, Pendukung (Support) merupakan perangkat pendukung berupa hardware dan software yang digunakan dalam membuat aplikasi pendapatan jasa.

\section{Hasil dan Pembahasan}

Sekolah Mengemudi Ar'rahman adalah institusi dalam jasa untuk kursus kendaraan roda empat atau mobil. Kemudahan dalam memahami sekolah tersebut, maka peneliti menggambarkan mulai tentang berdirinya, visi sekolah tersebut, misi sekolah tersebut, struktur dalam organisasi, fungsi dalam organisasi pada sekolah tersebut. Sekolah bertempat pada daerah Ibukota D.I. Jakarta, Ar'rahman sudah ada mulai 2000 sebagai tempat kursus untuk otomotif, penjahitan, operator pada komputer, lemari es, air conditioner, instalasi pada listrik 
serta skill lainnya. Ar'rahman melakukan pengembangan pada 2002 pada kursus untuk mengemudikan mobol dengan nama Sekolah Mengemudi Ar'rahman yang mempunyai alamat pada Jl. Inspeksi Saluran Kalimalang No E27, Kel. Pondok Bambu, Kec. Duren Sawit, Jakarta Timur. Sekolah Mengemudi Ar'rahman mempunyai ijin dalam menyelenggarakan sekolah untuk mengemudi mobil yang bernomor 185/-2014 pada tanggal 26 Maret 2014 dan ditetapkan oleh Dinas Perhubungan D.I. Jakarta.

Dalam Sekolah Mengemudi Ar'rahman memiliki income untuk jasa yang digunakan dalam peningkatan pendapatan institusi, namun dalam mencatat income jasa masih manual dengan dokumen berupa buku dalam melakukan pencatatan transaksi, dikarenakan adanya kendala dengan belum adanya sistem yang dapat memudahkan dalam pencatatan transaksi pada pendapatan jasa tersebut, sehingga berdampak pada kekeliruan dalam pelaporan income jasa.

Analisis dalam kebutuhan pada sistem diperlukan dalam pengajuan luaran yang berbentuk pelaporan income jasa pada setiap bulan. Perancangan aplikasi yang dilakukan agar memberikan kemudahan bagi pegawai dengan java language yang menggunakan tool Netbeans IDE 8.1 untuk membuat antarmuka pada aplikasi yang akan dibuat, XAMPP untuk web server, MySQL untuk database, i-Report untuk perancangan laporan.

\section{Prosedur Sistem Berjalan}

Berdasarkan gambar 1 Activity Diagram Proses Bisnis Sistem Berjalan, business process yang saat ini sedang berjalan pada Sekolah Mengemudi Ar'rahman adalah siswa mendatangi cabang dan melakukan tanya jawab mengenai paket pada kursus mengemudi. Sekretaris memberikan penjelasan mengenai biaya, banyaknya waktu, dan macam mobil dari paket mengemudi serta schedule dalam latihan mengemudi yang dibutuhkan oleh peserta kursus mengemudi.

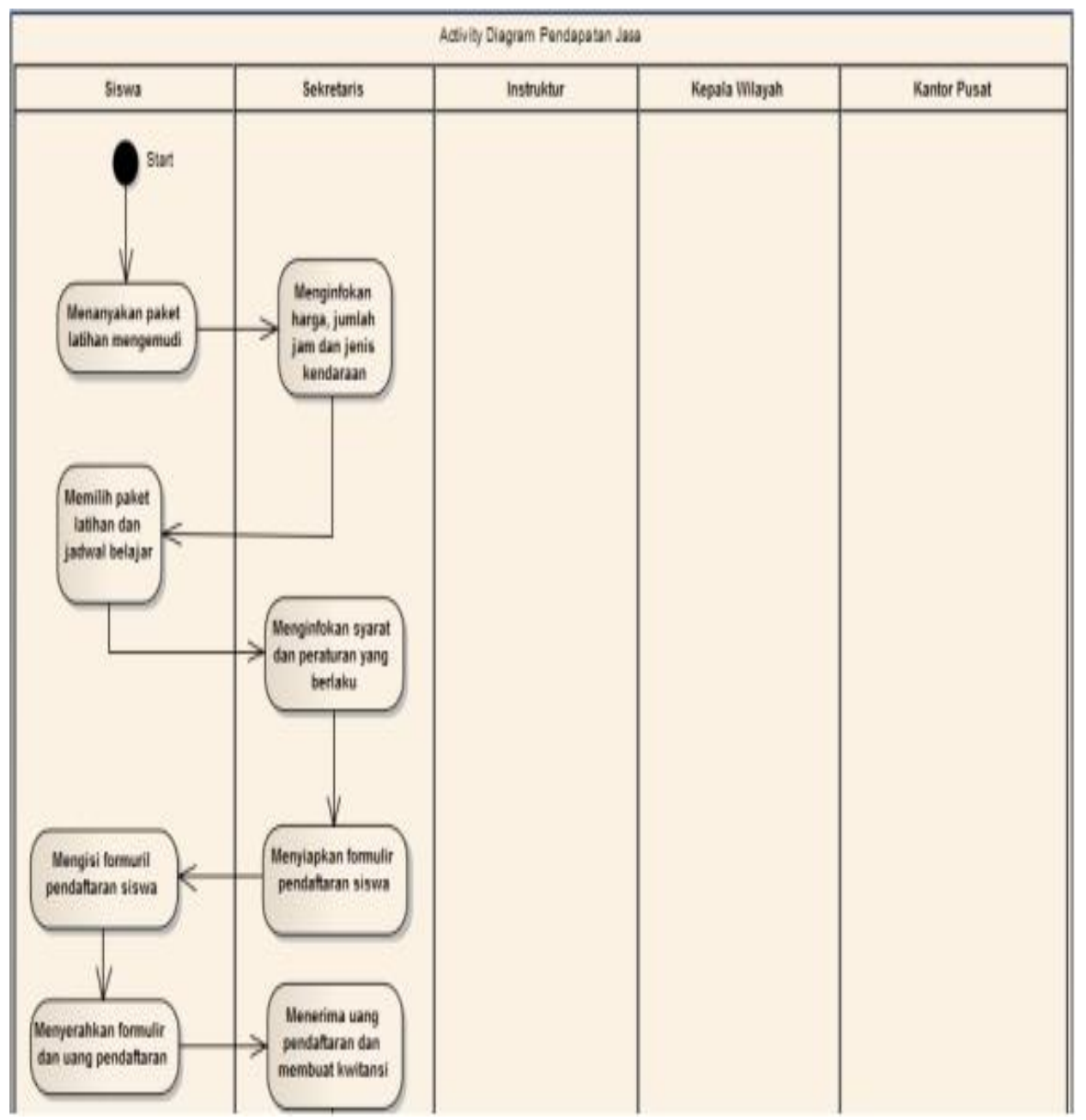




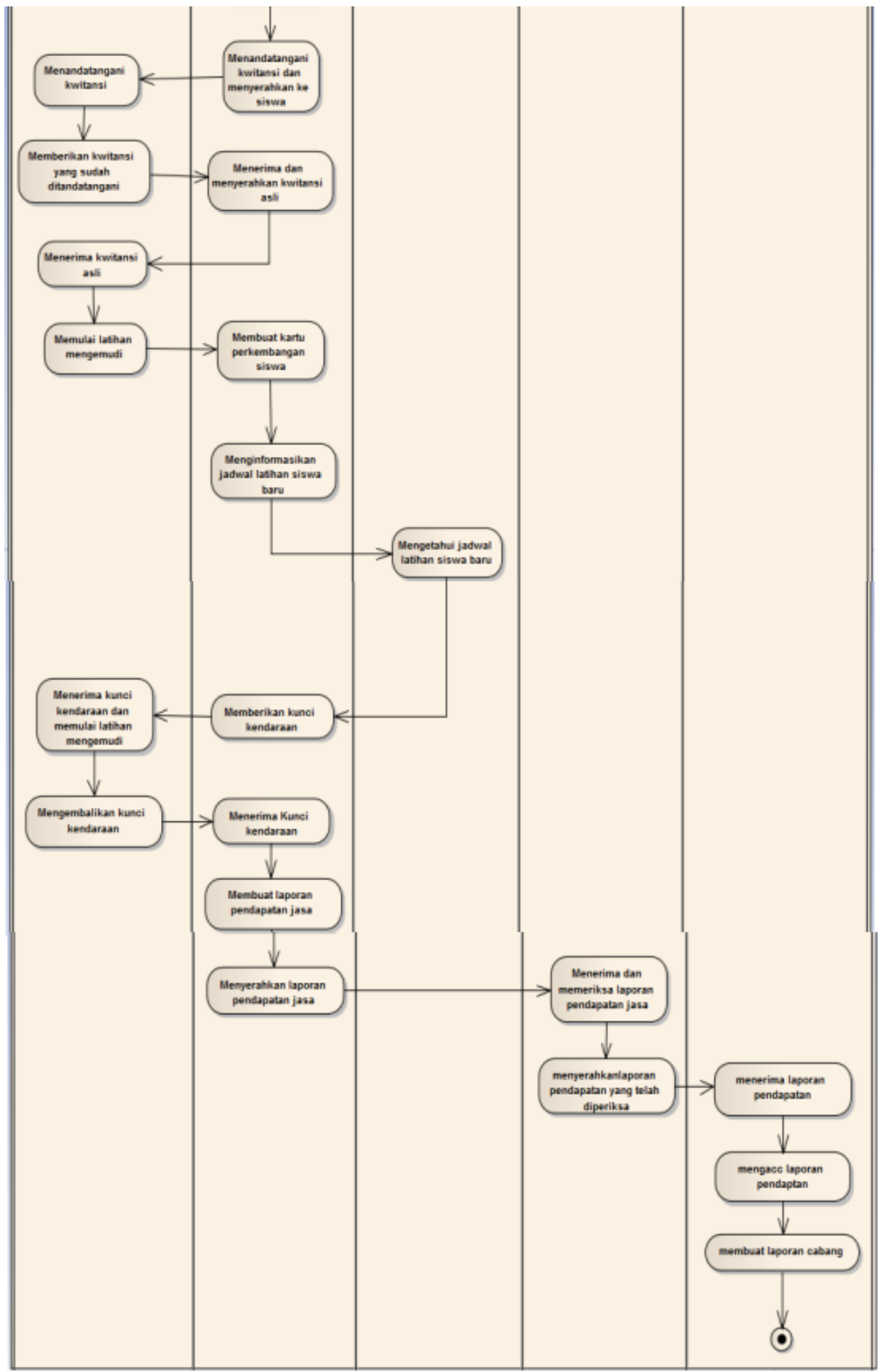

Sumber: Hasil Penelitian (2020)

Gambar 1. Activity Diagram Business Process System yang sedang Berjalan

Sekretaris memberikan informasi mengenai persyaratan dan ketentuan yang ada sebagai siswa di sekolah tersebut dan memberikan formulir untuk mendaftar sebagai siswa kursus mengemudi dan melakukan pelayanan terhadap pembayaran yang dilakukan. Sekretaris melakukan penerimaan terhadap siswa yang membayar pendafataran dengan membuatkan bukti berupa kwitansi. Siswa diharuskan melakukan penandatangan kwitansi dan memberikannya kembali kepada sekretaris lalu sekretaris melakukan penerimaan kwitansi yang 
sudah diserahkan siswa dan melakukan penyerahan kembali kepada siswa berupa kwitansi yang asli lalu dilanjutkan dengan siswa akan memulai dengan latihan dalam mengemudi. Kemudian sekretaris akan melakukan pembuatan kartu mengenai perkembangan terhadap siswa yang akan disampaikan kepada instruktur mengemudi dan selanjutnya instruktur akan melakukan pengisian terhadap kartu perkembangan tersebut yang disesuaikan dengan penjadwalan dalam kursus mengemudi untuk siswa tesebut. Sekretaris akan memberikan kunci mobil untuk pelatihan dalam mengemudi, pihak siswa akan melakukan penerimaan kunci tersebut dan dilanjutkan dengan latihan dalam mengemudi dengan instruktur. Jika sudah selesai, maka siswa harus mengembalikan kunci tersebut pada sekretaris. Sekretaris akan melakukan pembuatan pelaporan dalam pendapatan untuk jasa kursus mengemudi, lalu laporan tersebut akan disampaikan pada kepala wilayah untuk dilakukan pemeriksaan.

\section{Analisis Kebutuhan Software}

A1) Melakukan Login, A2) Mengakses Menu Utama, A2.1) Mengakses Menu Master Data, A2.2) Mengakses Menu Transaksi, A2.3) Mengakses Menu Informasi Data, dan A2.4) Mengakses Menu Laporan.

Berdasarkan gambar 2 mengenai Use Case Diagram di Menu Utama, admin dapat melakukan pengaksesan pada data yang tersedia pada main course seperti menu master data, menu transaksi, menu informasi data dan menu laporan. Pada langkah ini memungkinkan admin untuk mengakses sistem mulai dari input sampai dengan cetak laporan.

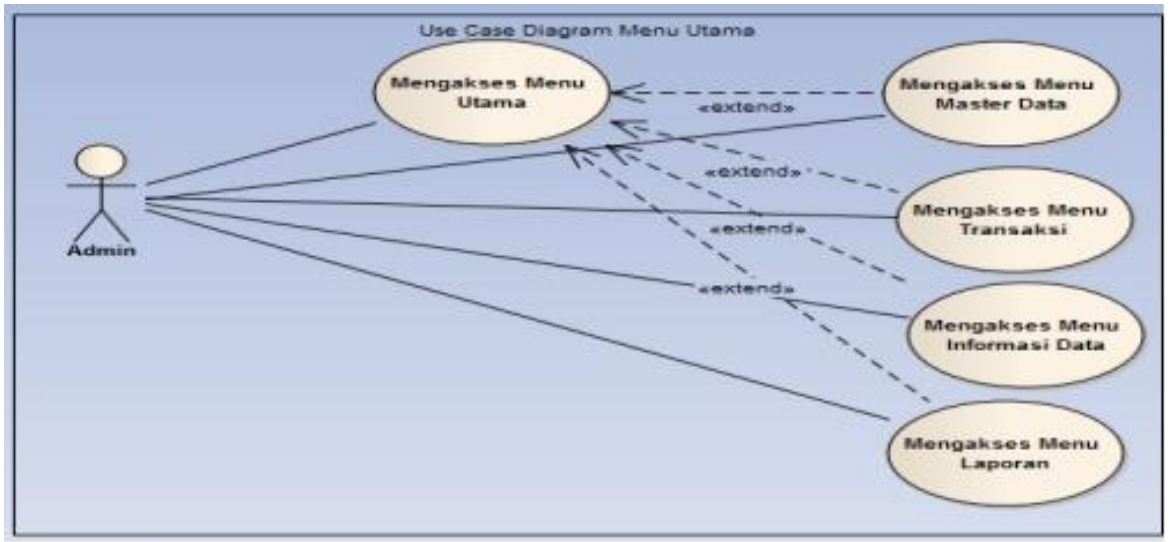

Sumber: Hasil Penelitian (2020)

Gambar 2. Use Case Diagram pada Menu Utama

Pada gambar 3, Activity Diagram menu utama dijelaskan bagaimana admin dapat mengakses menu utama sistem informasi pendapatan jasa.

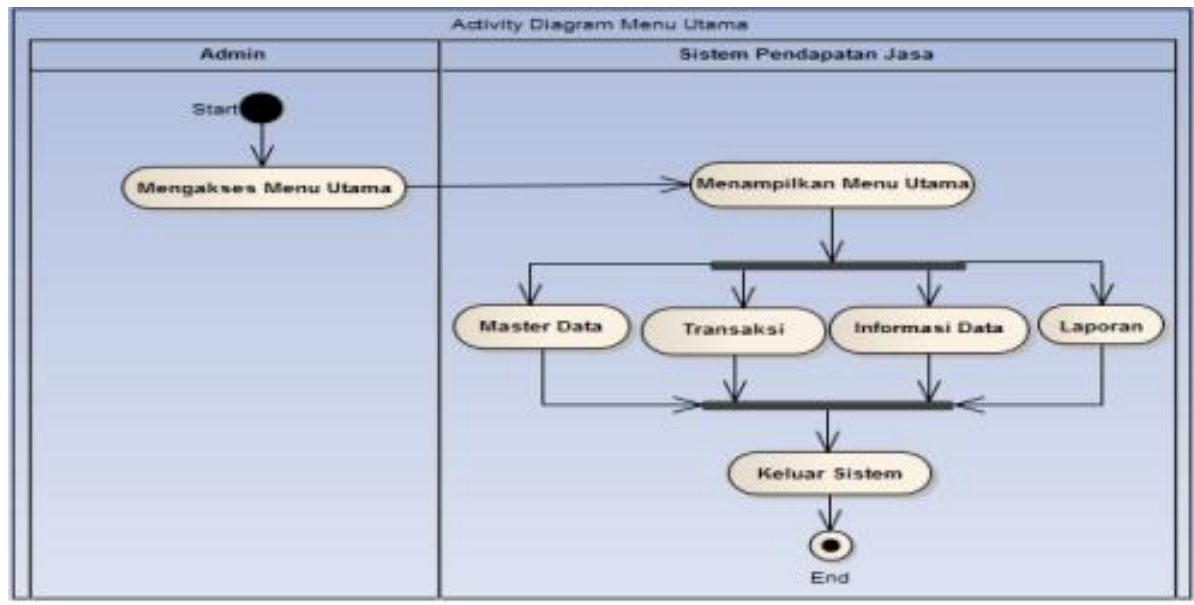

Sumber: Hasil Penelitian (2020)

Gambar 3. Activity Diagram Menu Utama 
Pada gambar 4, Entity Relationship Diagram (ERD) menggambarkan diagram untuk melakukan konektivitas dalam table beserta dengan field-field didalamnya pada sistem informasi pendapatan jasa. ERD terdiri dari 8 (Delapan) Tabel diantaranya: Satu, tabel Instruktur untuk menyimpan data Instruktur, tabel ini mempunyai field kd instruk dan nama instruk. Kedua, Tabel Siswa untuk menyimpan data siswa kursus, tabel ini mempunyai filed kd_siswa, nama, no_hp dan email. Ketiga, Tabel Kendaraan untuk menyimpan data kendaraan yang digunakan selama kursus, tabel ini mempunyai field kd kend, nm_kend dan jns_kendaraan. Keempat, tabel Paket untuk menyimpan data paket yang ditawarkan kepada siswa kursus, tabel ini mempunyai filed kd_paket, nama_paket dan harga. Kelima, tabel Pendaftaran untuk menyimpan transaksi pendaftaran siswa kursus, tabel ini mempunyai field no_pend dan tgl_pend. Keenam, tabel Pendaftaran detail untuk menyimpan detail data pendaftaran yang terdiri dari kd_instruk, kd_siswa, kd_kendaraan dan kd_paket yang sesuai dengan data pendaftaran. Ketujuh, tabel pembayaran untuk menyimpan transaksi pembayaran yang dilakukan oleh siswa kursus, yang terdiri dari field kd_pemb, tgl_pemb dan no_pend. Kedelapan, tabel Pembayaran detail untuk menyimpan detail data pembayaran yang terdiri dari field kd_pemb, kd_siswa, keterangan dan nominal.

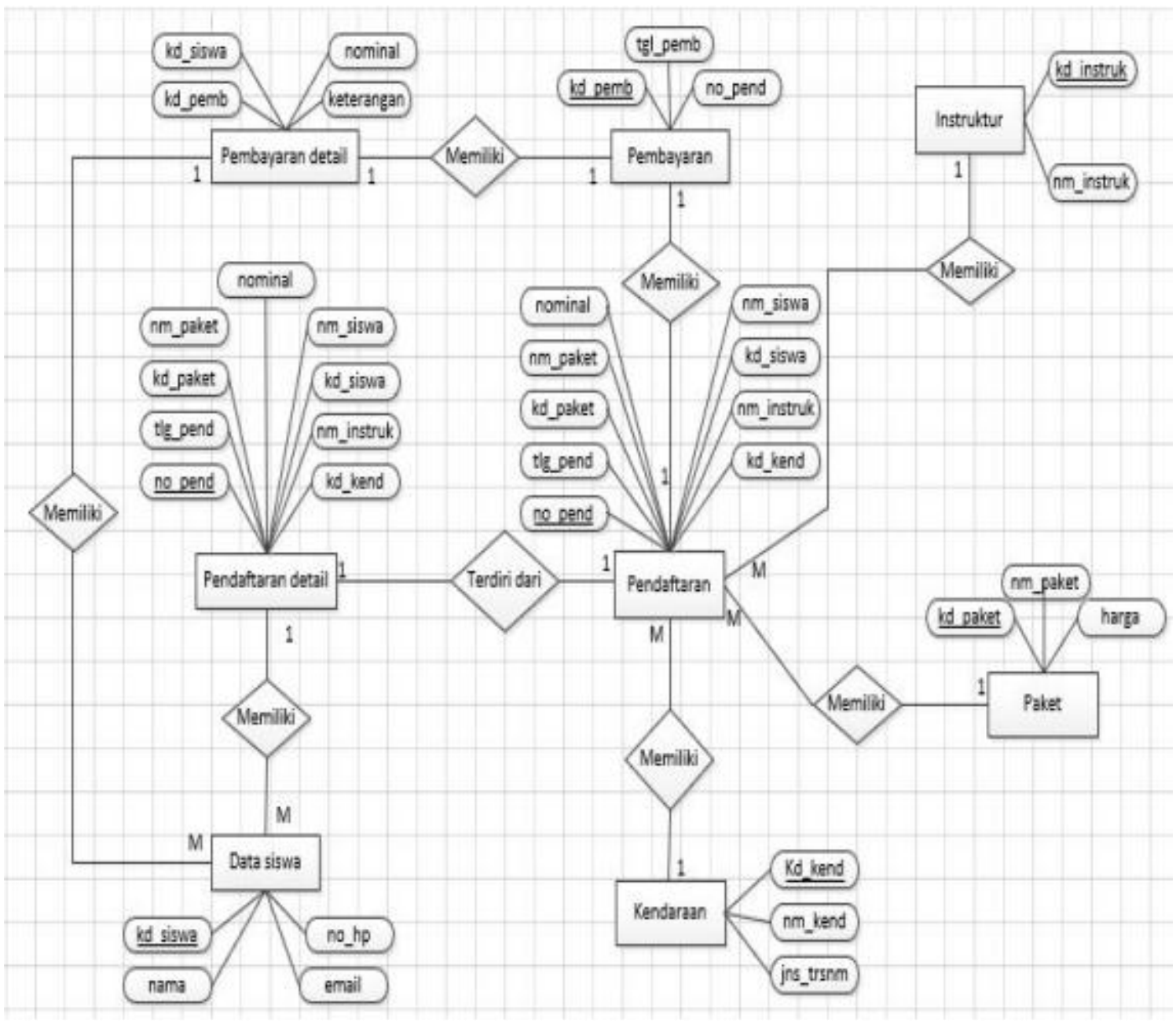

Sumber: Hasil Penelitian (2020)

Gambar 4. Entity Relationship Diagram (ERD)

Pada gambar 5. Logical Record Structure (LRS) adalah cara dalam menyusun data dari diagram yang terkoneksi dalam entity yang ada di $E R D$. 


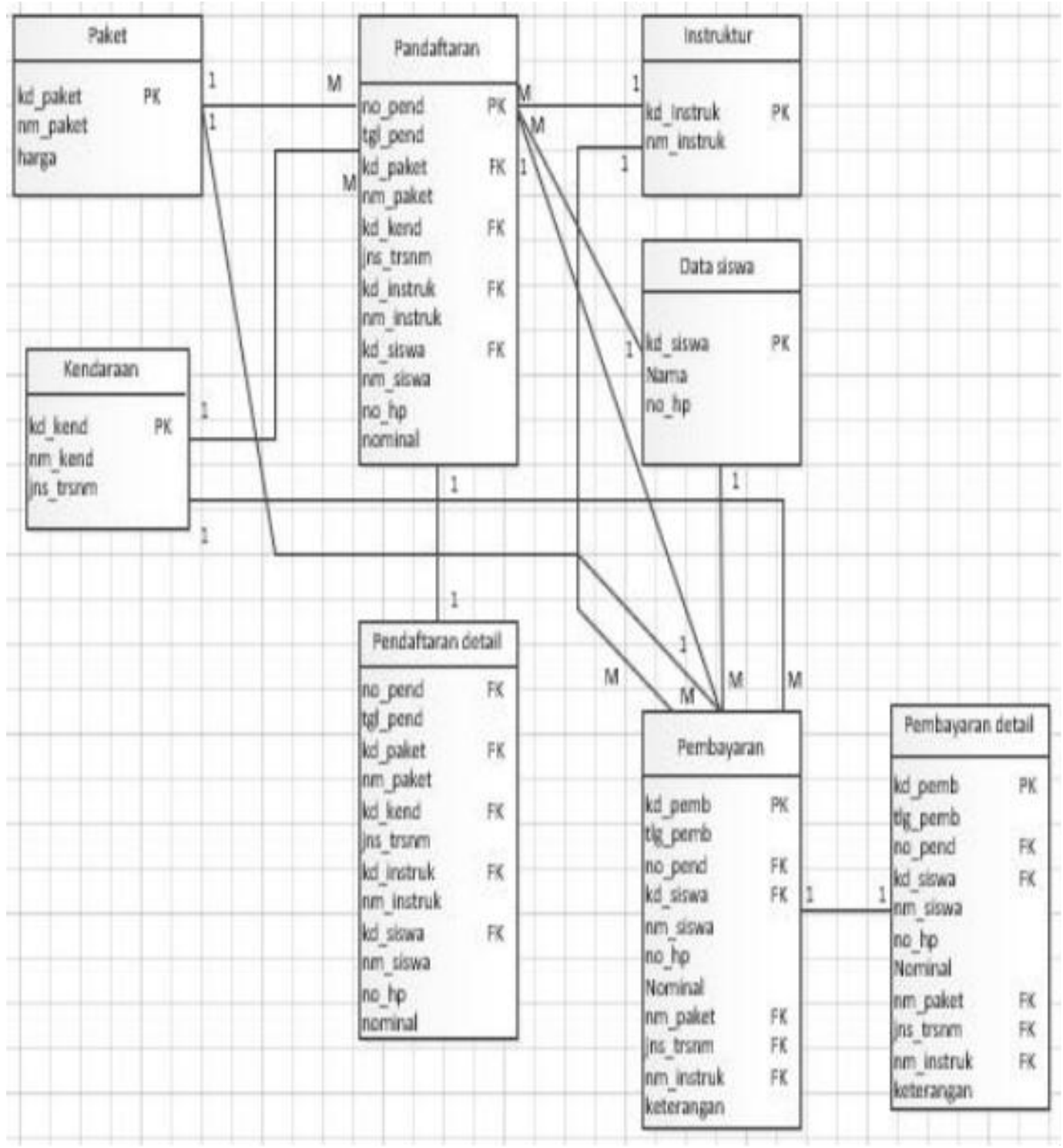

Sumber: Hasil Penelitian (2020)

Gambar 5. Logical Record Structure (LRS)

Pada tabel 1 menunjukan elemen data, tipe data dan panjang field yang ada dalam file kendaraan sebagai berikut, nama database pend_jasa, untuk penamaan file tabelnya yaitu kendaraan yang merupakan tipe file master, admin dapat mengakses file secara random, dengan panjang record 30 (tiga puluh) karakter dan kd_kendaraan dijadikan sebagai primary key.

Tabel 1. Spesifikasi File Kendaraan

\begin{tabular}{cllll}
\hline No & \multicolumn{1}{c}{ Nama Field } & \multicolumn{1}{c}{ Tipe Data } & Panjang & Keterangan \\
\hline 1. & kd_kend & varchar & 15 & Primary Key \\
\hline 2. & nm_kend & varchar & 15 & \\
\hline 3. & jns_trsnm & enum & 'MANUAL', 'AUTOMATIC' & \\
\hline
\end{tabular}

Sumber: Hasil Penelitian (2020)

Pada tabel 2 menunjukan elemen data, tipe data dan panjang field yang ada dalam file Pendaftaran sebagai berikut, nama database pend_jasa, untuk penamaan file tabelnya yaitu 
Pendaftaran yang merupakan tipe file Transaksi, admin dapat mengakses file secara random, dengan panjang record 40 (empat puluh) karakter dan no_pend dijadikan sebagai primary key.

Tabel 2. Spesifikasi File Pendaftaran

\begin{tabular}{cllll}
\hline No & \multicolumn{1}{c}{ Nama Field } & \multicolumn{1}{c}{ Tipe Data } & Panjang & Keterangan \\
\hline 1 & no_pend & varchar & 10 & Primary Key \\
\hline 2 & tgl_pend & date & & \\
\hline 3 & kd_paket & varchar & 10 & Foreign Key \\
\hline 4 & jns_trsnm & ENUM & 'MANUAL', 'AUTOMATIC' & Foreign Key \\
\hline 5 & nm_instruk & varchar & 20 & Foreign Key \\
\hline
\end{tabular}

Sumber: Hasil Penelitian (2020)

Pada tabel 3 menunjukan elemen data, tipe data dan panjang field yang ada dalam file Pendaftaran Detail sebagai berikut, nama database pend_jasa, untuk penamaan file tabelnya yaitu Pendaftaran_detail yang merupakan tipe file Transaksi, admin dapat mengakses file secara random, dengan panjang record 60 (enam puluh) karakter dan no_pend, kd_siswa, dijadikan sebagai foreign key.

Tabel 3. Spesifikasi File Pendaftaran Detail

\begin{tabular}{clllll}
\hline No & \multicolumn{1}{c}{ Nama Field } & \multicolumn{1}{c}{ Tipe Data } & & Panjang & Keterangan \\
\hline 1 & no_pend & varchar & 10 & Foreign Key \\
\hline 2 & kd_siswa & varchar & 10 & Foreign Key \\
\hline 3 & no_hp & varchar & 15 & \\
\hline 4 & Nominal & text & & \\
\hline
\end{tabular}

Sumber: Hasil Penelitian (2020)

Pada tabel 4 menunjukan elemen data, tipe data dan panjang field yang ada dalam file Pendaftaran Detail sebagai berikut, nama database pend_jasa, untuk penamaan file tabelnya, yaitu: Pendaftaran_detail yang merupakan tipe file Transaksi, admin dapat mengakses file secara random, dengan panjang record 25 (dua puluh lima) karakter dan no_pend, kd_siswa, dijadikan sebagai foreign key.

Tabel 4. Spesifikasi File Pembayaran

\begin{tabular}{cllll}
\hline No & \multicolumn{1}{c}{ Nama Field } & \multicolumn{1}{c}{ Tipe Data } & Panjang & Keterangan \\
\hline 1 & kd_pemb & varchar & 10 & Primary Key \\
\hline 2 & tgl_pemb & date & & Foreign Key \\
\hline 3 & no_pend & varchar & 15 & \\
\hline
\end{tabular}

Sumber: Hasil Penelitian (2020)

Pada tabel 5 menunjukan elemen data, tipe data dan panjang field yang ada dalam file Pendaftaran Detail sebagai berikut, nama database pend_jasa, untuk penamaan file tabelnya yaitu Pendaftaran_detail yang merupakan tipe file Transaksi, admin dapat mengakses file secara random, dengan panjang record 45 (empat puluh lima) karakter dan no_pend, kd_siswa, dijadikan sebagai foreign key.

Tabel 5. Spesifikasi File Pembayaran Detail

\begin{tabular}{cllll}
\hline No & \multicolumn{1}{c}{ Nama Field } & \multicolumn{1}{c}{ Tipe Data } & Panjang & Keterangan \\
\hline 1 & kd_pemb & varchar & 10 & Foreign Key \\
\hline 2 & kd_siswa & varchar & 10 & Foreign Key \\
\hline 3 & Nominal & text & & \\
\hline 4 & Keterangan & text & & \\
\hline
\end{tabular}

Sumber: Hasil Penelitian (2020) 


\section{User Interface}

User Interface Login, untuk membatasi, mengakses dan memverifikasi pengguna adalah fungsi dari halaman login, dengan cara pengguna memasukan nama pengguna dan kata kunci yang sudah terdaftar sebelumnya. Tombol Login digunakan untuk memverifikasi nama pengguna dan kata kunci yang dimasukan sebelumnya jika benar maka pengguna dapat mengakses halaman selanjutnya, jika tidak user harus menginput nama pengguna dan kata kunci yang benar atau dapat membatalkan proses.

User Interface Menu Utama, pengguna dapat mengakses Halaman Master Data, Transaksi dan Laporan jika sudah berhasil login pada halaman login. Berikut ini adalah deskripsi dari page tersebut.

User Interface Menu Master, pada menu Master ini pengguna dapat mengakses beberapa data master diantaranya: Halaman Instruktur pengguna dapat menambahkan, melihat, mengedit dan menghapus kode dan nama Instruktur. Halaman Siswa pengguna dapat menambahkan, melihat, mengedit dan menghapus Kode, Nama, Telp dan email Siswa. Halaman Kendaraan pengguna dapat menambahkan, melihat, mengedit dan menghapus kode, nama dan jenis kendaraan. Halaman Paket pengguna dapat menambahkan, melihat, mengedit dan menghapus kode, nama dan harga paket.

User Interface Menu Transaksi, pada menu Transaksi ini pengguna dapat mengakses beberapa data master diantaranya: Halaman Pendaftaran pengguna dapat melihat dan menambahkan transaksi pendaftaran siswa dengan mengklik tombol tambah lalu memasukan kode paket, kode kendaraan dan kode Instruktur kemudian diklik simpan. Halaman Pembayaran pengguna dapat melihat dan menambahkan transaksi pembayaran dengan mengklik tombol tambah dan memasukan nomor pendaftaran lalu disimpan.

User Interface Menu Laporan, pada menu Laporan pengguna dapat melihat laporan dari transaksi Pendaftaran dan Laporan Pembayaran selama 1 bulan.

\section{Spesifikasi Hardware}

$\begin{array}{ll}\text { Sistem } & : \text { Windows 7 Ultimate 64-bit version } \\ \text { Processor } & : \text { Intel Core i3-23700M CPU @ 2.50GHz } \\ \text { RAM } & : 2 \mathrm{~GB} \\ \text { Hardisk } & : 512 \mathrm{~GB} \\ \text { Monitor } & : 14 \text { Inc LED Display } \\ \text { Keyboard } & : \text { Standard } \\ \text { Mouse } & : \text { Standard }\end{array}$

\section{Spesifikasi Software}

Bahasa Pemrograman : Java Netbeans IDE 8.1

Aplikasi Pendukung : XAMPP

DBMS : MySQL (phpMyAdmin)

Anti Virus : Smadav

\section{Kesimpulan}

Sekolah Mengemudi Ar'rahman merupakan perusahaan yang bergerak di bidang jasa kursus mobil yang memiliki banyak cabang salah satunya berada di daerah Pangkalan Jati, pencatatan data transaksi pendapatan jasanya masih manual. Berdasarkan permasalahan tersebut kesimpulan yang didapatkan adalah: Pertama, Sulitnya melakukan pencarian data apabila diperlukan karena tidak memiliki backup data dari setiap Pendaftaran maupun Pembayaran dari siswa. Kedua, Aplikasi yang menggunakan basis dekstop dengan java language dan tool NetBeans IDE versi 8.1 untuk membuat antarmuka aplikasi, XAMPP untuk web server dan phpMyAdmin untuk database. Sehingga bisa membantu mempercepat dalam pengelolaan data dan menghemat waktu serta terhindar dari kesalahan pemasukan data. 
Ketiga, Pembuatan jadwal kursus dan laporan menjadi lebih efektif dan efisien, juga data yang dihasilkan lebih akurat.

\section{Referensi}

[1] S. Faizah, "Perancangan Program Penjualan," J. Sist. Inf., vol. IV, no. 2, pp. 208-214, 2015.

[2] U. Syifaunnisa and S. Faizah, "Transaksi Data Keuangan PD. Mekar Wangi Abadi Menggunakan Zahir Accounting Versi 5.1," BINA Insa. ICT J., vol. 5, pp. 113-122, 2018.

[3] I. Ariyati, "Sistem Informasi Penjualan Obat Herbal secara Online," Inf. Manag. Educ. Prof., vol. 1, no. 1, pp. 11-21, 2016.

[4] Krismiaji, Sistem Informasi Akuntansi. Yogyakarta: Sekolah Tinggi IImu Manajemen YKPN, 2015.

[5] Bahri, Sistem Informasi Akutansi. Jakarta: Andi Offset, 2016.

[6] S. Faizah, N. R. Susanti, and E. Pujiastuti, "Sistem Informasi Pengeluaran Kas Pada Yayasan Dana Pensiun Askrida Berbasis Web," vol. 4, no. 2, pp. 123-132, 2020.

[7] J. J. Weygandt, D. E. Kieso, and Paul D. Kimmel, Accounting Principles Pengantar Akuntansi. Jakarta: Salemba Empat, 2014.

[8] R. A.S and M. SHALAHUDDIN, Rekayasa Perangkat Lunak Terstruktur dan Berorientasi Objek. Bandung: Informatika.

[9] Mustakini, Sistem Informasi Teknologi. Yogyakarta: Andi Offset, 2014.

[10] Novriadi, Java Fundamental dengan Netbeans 8.0.2. Yogyakarta: Deepublish, 2015. 